\title{
COMPARATIVE STUDY BETWEEN DIFFERENT SOIL AMENDMENTS FOR IMPROVING SOME SOIL PROPERTIES AND WHEAT PRODUCTIVITY IN SALINE SODIC SOIL \\ Hamad .M.M.H.
}

Soils, Water and Environment Res. Ins., Agric. Res. Center, Giza, Egypt.

\begin{abstract}
Two field experiments were carried out at El-Hussynia Research Station, Port Said Governorate, during two successive winter seasons (2012|2013 and 2013|2014), to study the effect of sugar industrial wastes (filter mud and sugar lime); gypsum and elemental sulphur which was added alone or combined with them under different irrigation intervals on some soil physical and chemical properties and water use efficiency. The treatments that subjected in this study were eight treatments; untreated i.e, control, gypsum at a rate of 4 ton fed $^{-1}$, elemental sulphur at a rate of 0.5 ton/fed, industrial wastes (mixture of filter mud and sugar lime $2: 1 \mathrm{w} / \mathrm{w}$ ) at a rate of 4.5 ton/fed as well as their combination under two irrigation intervals of 12 and 18 days.

With regard to soil physical properties, data revealed that application of amendments and/or sugar industrial wastes under two irrigation intervals increased the aggregates size distribution particularly of $(2-1 \mathrm{~mm})$ in diameter and total water stable aggregates. At the same time these treatments decreased the fine aggregates size $(<0.125 \mathrm{~mm})$ in diameter. Consequently, infiltration rate and available water were increased while bulk density was decreased, particularly in the surface layer $(0$ $20 \mathrm{~cm}$ ) in the presence of applied gypsum + sulphur combined with (filter mud + sugar lime) under 12 days of irrigation interval as compared with the other treatments.

As for the chemical properties, data showed that $\mathrm{pH}, \mathrm{EC}, \mathrm{ESP}$ and O.M were positively affected either by applied gypsum, sulphur and/or filter mud + sugar lime particularly in the surface layer $(0-20 \mathrm{~cm})$ under 12 days of irrigation interval as compared with other treatments. Also, the grain content of the three nutrients elements (N P and K) was increased.

Wheat grain yield, straw yield and water use efficiency were enhanced in response to application of amendments under irrigation intervals as compared with the untreated soil.

The improvement of some soil physical and chemical properties as well as increasing wheat yield and water use efficiency, was achieved for interaction between 1.5 ton gypsum +0.5 ton sulphur +2.0 ton filter mud +1.0 ton sugar lime per feddan under 12 days irrigation interval.

Keywords : Saline sodic soil , filter mud , Sugar lime , Gypsum , Sulphur , Irrigation intervals, Soil physiochemical properties and Water use efficiency.
\end{abstract}

\section{INTRODUCTION}

Reclamation of saline sodic soils includes leaching of the soluble salts and applying proper amendments such as gypsum, sulphur and organic materials. In Egypt, the soils are very poor in their organic matter content due to the climatic arid conditions and high decomposition rate of organic matter. Furthermore, there is a tremendous mass of industrial by products which can 
be used for some soil properties development. Some of these are the filter mud ( produce from sugarcane factories) about $400-500 \times 10^{3}$ ton/year which was thrown in the Nile River causing pollution of the water environment and sugar lime (produce from sugar beet factories) about $2.5 \times 10^{6}$ ton/year as by product obtained from the sugar industries, which are increased year by year. Using such byproducts could have an economical value as a soil conditioner. In this respect, the use of filter mud in sodic soil leads to improve some soil chemical properties, i.e., pH, EC, CEC, OM and nutrients status (Mohamed et al., 2001). Mansour (2002) and Reda et al. (2006) reported that application of filter mud, sugar lime and sulphur decreased bulk density, wilting point and fine capillary pores. While, field capacity, available water content, total porosity, quickly and slowly drainable pores as well as grain and straw yields of wheat plants were increased referring to the control (untreated soil). Mansour (2002) showed that filter mud is a waste product from sugarcane factories, it is a soft ,spongy, light weight material of dark gray .The main bulk of the material is organic matter $(75 \%)$ with relatively low $\mathrm{pH}$, and sugar lime is a waste product of the sugar refinery industry (from sugar beet factories). It is an aggregated powder of light brown colour. The lumps break down easily to very fine powder on the soil surface. The main bulk of the material is $\mathrm{Ca}$ $\mathrm{CO}_{3}$ with the relatively high $\mathrm{pH}$ value (8.3).

It is well established that the proper application of appropriate soil amendments as gypsum and mineral sulphur will improve soil physicochemical properties, which lead in turn to increase crop productivity. In this connection gypsum is the most common $\mathrm{Ca}^{2+}$ source which removes a large portion of $\mathrm{Na}^{+}$from the soil profiles and improves the physical condition by promotion flocculation enhacing mean weight diameter, aggregate stability and consequently decreasing soil bulk density especially in the surface layers than the subsurface ones and increasing water flow as well as the productivity of suger beet plants in saline sodic soil . In addition gypsum application increased soil moisture content. That the treatments received gypsum had higher available water content after the second year (Aly, 1993 and Abd El-Hamid et al.,2005). Usually, a soil amendment with an acidification effect is used in the reclamation of sodic soils the acidification effect of sulphur exceeds that of all other amendments, e .g ., sulphuric acid and gypsum ( Wahdan et al ., 1999). In addition , the method of sulphur application to soils is simple and does not require special tools or equipment. Moreover, the application of excessive amounts of sulphur does not result in harmful effects to man, plant, microorganisms or drainage water (Khafagi and Abdel Hadi, 1990). Abdel-Aziz et al. (1998) reported that the application of gypsum and sulphur decreased soil salinity, $\mathrm{pH}$ and ESP. Mohamedin et al. (2005) added that the application of gypsum and lime as amendments in sodic soil enhanced the infiltration rate and decreased soil pH ,EC and ESP, as well as increased the productivity of rice and wheat. Water is the most limiting factor in extension of cultivated areas in Egypt. Thus, it is essential to know the optimum time to apply limited amount of irrigation water to obtain maximum crop yields, increase the agricultural production per unit volume of water use efficiency (El-Maghraby , 1997). Mansour, et al (2012) showed that the usage of any acidic soil amendments 
treatment (Azotobacter spp, diluted sulphuric acid, sheep manure, vinasse and the combination of them) could positively affect the soil physio-chemical and biological properties i.e., $\mathrm{pH}$, total and active $\mathrm{CaCO}_{3}$ content, available $\mathrm{Ca}^{2+}$, bulk density and fine capillary pores. On the contrary, hydraulic conductivity, total porosity, $\mathrm{EC}_{\mathrm{e}}$, and total yield increased. Furthermore, enzymes activities (nitrogenase and dehydrogenase) and $\mathrm{CO}_{2}$ evolution was increased especially by the application of vinasse or Azotobacter spp. Mansour et al (2014) concluded that using any amendments (sugar lime ,vinasse, by-pass, pyrite $\left(\mathrm{FeS}_{2}\right)$ and aluminum sulfate $\left(\mathrm{Al}_{2}\left(\mathrm{SO}_{4}\right)_{3} 18 \mathrm{H}_{2} \mathrm{O}\right)$ individual and interaction among them tested in this study were effective in saline-sodic soil reclamation as well as improved the physical properties of the soil (Ks, B.D, P.R and WTD) and chemical properties, (EC, pH and ESP).

The present investigation aims to study the effects of different soil amendments under two irrigation intervals as a tool for improving some physical and chemical properties of soil at El-Hussynia plain and its productivity of wheat.

\section{MATERIALS AND METHODS}

Two field experiments were carried out at El-Hussynia Research Station, Port Said Governorate, during two successive winter seasons (2012/2013 and 2013/2014), to study the effect of different soil amendments on some properties of saline sodic soil and its productivity under two irrigation interval. Some physiochemical properties of the studied soil are shown in Table (1). The chemical analysis of the used water for irrigation is shown in Table (2).

Table (1) : Some physiochemical properties of the experimental soil.

\begin{tabular}{|l|c|}
\hline Soil characteristics & Value \\
\hline A. particle size distribution & 1.40 \\
Coarse sand $(\%)$ & 10.79 \\
Fine sand (\%) & 23.46 \\
Silt $(\%)$ & 64.35 \\
Clay Clay \\
Soil texture $(\%)$ & \\
B. chemical analysis & 8.51 \\
pH (1:2.5 soil susp.) & 6.21 \\
ECe (soil paste extract) $\left(\mathrm{dSm}^{-1}\right)$ & 1.26 \\
Organic matter (\%) & 1.43 \\
$\mathrm{CaCO}$ & 17.6 \\
$\mathrm{ESP} \quad(\%)$ & \\
\hline
\end{tabular}


Table (2): Chemical analysis for irrigation water.

\begin{tabular}{|c|c|c|c|c|c|c|c|c|c|}
\hline \multirow[t]{2}{*}{ pH } & \multirow{2}{*}{$\begin{array}{c}E C \\
\left(d S^{-1}\right)^{2}\end{array}$} & \multicolumn{4}{|c|}{$\begin{array}{l}\text { Cations } \\
\text { mmol }^{-1} \mathrm{~L}^{-1}\end{array}$} & \multicolumn{3}{|c|}{$\begin{array}{c}\text { Anions } \\
\text { mmol }_{c} \mathrm{~L}^{-1}\end{array}$} & \multirow[t]{2}{*}{ SAR } \\
\hline & & $\mathrm{Ca}^{2+}$ & $\mathrm{Mg}^{2+}$ & $\mathrm{Na}^{+}$ & $\mathrm{K}^{+}$ & $\mathrm{HCO}_{3}{ }^{-}$ & $\mathrm{Cl}^{\circ}$ & $\mathrm{SO}_{4}{ }^{2-}$ & \\
\hline 7.83 & 1.30 & 2.06 & 4.00 & 6.48 & 0.31 & 2.51 & 7.28 & 3.06 & 3.72 \\
\hline
\end{tabular}

A factorial experiment was conducted in a complete spilit block design with three replicates having plot area of $3 \times 3.5 \mathrm{~m} .\left(10.5 \mathrm{~m}^{2}\right.$.). The treatments were:

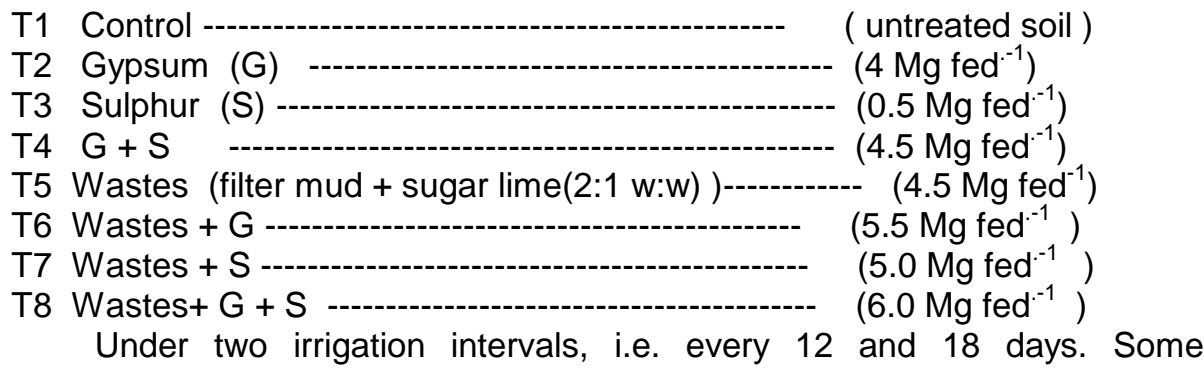
characters of sugar industrial wastes are presented in Table (3). Amendments were uniformly applied on the soil surface and thoroughly mixed in top $30 \mathrm{~cm}$ soil depth and then followed by irrigation with desired depth of water.

Table ( 3 ) : Chemical composition of the mixture of filter mud and sugar lime used

\begin{tabular}{|lc|c|}
\hline \multicolumn{2}{|l|}{ Components and characteristics } & Value \\
\hline Moisture & 4.57 \\
Organic carbon & $(\%)$ & 39.8 \\
Organic matter & $(\%)$ & 68.5 \\
Total nitrogen $\quad(\%)$ & 2.34 \\
Total phosphorus $\quad(\%)$ & 4.56 \\
Total potassium $\quad(\%)$ & 0.71 \\
$\mathrm{C} / \mathrm{N}$ ratio & 17.0 \\
$\mathrm{pH}(1: 5$ mixture sups.) & 8.20 \\
$\mathrm{CaCO}_{3} \quad(\%)$ & 23.71 \\
\hline
\end{tabular}

The plots were sown by grains of wheat cv, ( Sakha 93 ), in 15 and 17 November in the two seasons. The recommended doses of NPK fertilization , [ phosphorus in the form of superphosphate $\left(15 \% \mathrm{P}_{2} \mathrm{O}_{5}\right)$ at a rate of $300 \mathrm{~kg}$ fed $^{-1}$ before planting, nitrogen fertilizer in the form of ammonium nitrate $(33.5 \% \mathrm{~N})$ at a rate of $150 \mathrm{~kg} \mathrm{fed}^{-1}$ was applied in three doses and potassium fertilizer in the form of potassium sulphate $\left(48 \% \mathrm{~K}_{2} \mathrm{O}\right)$ at a rate of $50 \mathrm{~kg} \mathrm{~K}_{2} \mathrm{O}$ / $\mathrm{fed}^{-1}$. Plants were harvested at maturity stage, grain and straw yield of wheat were recorded. Also, soil samples were taken at harvest stage. Water consumptive use according to (Israelsen and Hansen,1962) using the following formule: 
Water consumptive use $\left(\mathrm{m}^{3} \mathrm{fed}^{-1}\right)=\frac{(\theta \mathrm{a}-\theta \mathrm{b})}{100} \times \mathrm{BD} \times \mathrm{D}$

Where: $\theta$ a $=$ soil moisture percentage on weight basis after 48 hours of irrigation.

$\theta b=$ soil moisture percentage on weight just before the next irrigation $\mathrm{BD}=$ Bulk density $\left(\mathrm{g} \mathrm{cm}^{-3}\right)$

$\mathrm{D}=$ soil depth $(\mathrm{cm})$.

Grain yield $\left(\mathrm{kg} \mathrm{fed}{ }^{-1}\right)$

Water use efficiency $\left(\mathrm{kg} \mathrm{m}^{3}\right)=$

$$
\text { Water consumptive use }\left(\mathrm{m}^{3} \mathrm{fed}^{-1}\right)
$$

Methods:

\begin{tabular}{|c|c|}
\hline Soil properties & Publishers \\
\hline${ }^{\star}$ Particle size distribution (\%) & Gee and Bauder (1986) \\
\hline${ }^{\star}$ Bulk density $\left(\mathrm{gcm}^{-3}\right)$ & Vomocil (1965) \\
\hline $\begin{array}{lr}\text { * Soil reaction }(\mathrm{pH}) \text { and EC } & \left(\mathrm{dSm}^{-1}\right) \\
\text { Organic matter content } & \left(\mathrm{g} \mathrm{kg}^{-1}\right) \\
\text { ESP } & (\%)\end{array}$ & Page et al (1982) \\
\hline $\begin{array}{l}{ }^{*} \text { water use efficiency }\left(\mathrm{Kg} \mathrm{m} \mathrm{m}^{3}\right)=\text { Grain yield }(\mathrm{kg} \\
\left.\mathrm{fed}^{-1}\right) / \text { water consumptive use }\left(\mathrm{m}^{3} \mathrm{fed}^{-1}\right)\end{array}$ & Jensen (1983) \\
\hline${ }^{*}$ Total N. & Issac and Junson (1976 ) \\
\hline * Total P,K. & Jackson ( 1967) \\
\hline${ }^{*}$ Basic Infiltration rate & (Richards, 1954) \\
\hline Water stable aggregates* & Kemper and Rosenau (1986) \\
\hline Soil moisture & Stakman and Harst . (1962) \\
\hline
\end{tabular}

\section{RESULTS AND DISCUSSION}

\section{Effect of soil amendments on some physical properties: 1-Water stable aggregates:}

The amounts of water stable aggregates in the soil is a good index for testing the structure stability. Data in Table (4) show that aggregates size of $(2-1 \mathrm{~mm})$ in the soil samples was found to be the most responsive to applied treatments,i.e., gypsum, sulphur and /or the mixture or both (filter mud and sugar lime). The highest value of the aggregate size of $(2-1 \mathrm{~mm})$ was recorded with application of filter mud + sugar lime supported by gypsum + sulphur under 12 days of irrigation interval compared with control. Hence, it represented about of $37.9 \%$ and $36.7 \%$ of total aggregates in both surface and subsurface layers, respectively. Data also show that the water stable structural unit $(<0.125 \mathrm{~mm})$ in diameter was decreased and reached to $50.89 \%$ and $55.89 \%$ when soil treated with a mixture of filter mud+ sugar lime supported to gypsum + sulphur under 18 days irrigation interval in both surface and subsurface layers These results agree with Aly (1993) and Abd EL- Hamid et at . (2005). Concerning the aggregates size (1-0.5 mm), (0.5 $0.25)$ and (0.25- 0.125), data revealed that there was an increase in their aggregate size in the treated soils compared with untreated ones (control) in both surface and subsurface layers. 
Hamad .M.M.H.

1006 
With regard to total aggregates, the application of sugar industrial wastes, gypsum and sulphur in a single form or combined enhanced the formation of total aggregates. The highest values of total aggregates were obtained when the saline sodic soil treated with 3.0 ton filter mud +1.5 ton sugar lime +1.0 ton gypsum and 0.5 ton sulphur ) per feddan. Such results were in agreed with those reported by EL-Maghraby (1997) who found that the positive effect of organic manure on enhancing the formation of stable aggregates could be due to that, such materials serve as cementing. As the microbial decay of organic matter of these materials produced polymers (such as polysaccharide and polymorinides ) capable for binding aggregates and the exudates of sulphur bacteria and the increases in $\mathrm{Ca}$ ions due to sulphur and gypsum application act as cementing for the aggregates (Wassif et al ., 1999) and Mansour, et al.2012).

This could be explained as follows: the frequent soil wetting and drying under short irrigation intervals caused differential expansion and shrinkage which promotes the formation and stabilization of soil aggregates (Hillel,1980). However, the higher salt concentration in soil solution under long irrigation intervals (Table, 5) may be adversely affect the formation of water stable aggregates (Afify,1983 and El-Maghraby,1997).

2-Soil bulk density:

Data in Table (5) revealed that the application of filter mud+sugar lime, gypsum or sulphur as mixtures of them under two irrigation intervals led to decrease soil bulk density compared with untreated soil. The mixture of sugar industrial wastes with gypsum and sulphur was more effective, particularly with 12 days irrigation interval compared with other treatments. This could be attributed to decomposition wastes which effect the bulk density through aggregation process. These results are in consistent with those of Abdel- Aziz et al. (1998) who observed an improvement in bulk density of the sodic soil when treated with gypsum and sulphur. Mansour (2002) added that the application of filter mud and sugar lime to sodic soil significantly decreased the bulk density. These results are in agreements with those obtained by Mansour et al (2014).

3-Infiltration rate:

Results of basic infiltration rate in saline sodic soil treated with industrial wastes, gypsum and sulphur individually or combined with them under 12 and 18 days irrigation intervals are listed in Table (5).It is clear that the basic infiltration rate was increased under all treatments as compared with the control. The industrial wastes supported by gypsum and sulphur application were more effective, particularly under 12 days irrigation interval. These results are in agreement with those obtained by Mohamedin et al.(2005) who reported that the application of organic manure, lime and gypsum increased infiltration rate in sodic soil.

\section{4-Available water:}

Data in Table (5) also show the positive effect of different soil amendments either separately or in a mixture of them on available soil moisture in saline sodic soil. The highest values were associated with application of filter mud + sugar lime supported by gypsum +sulphur compared with untreated soil, particularly at 12 days irrigation interval in surface layer. It is worthy to mention that the rate of increase in soil moisture content at field capacity was higher than at wilting point, consequently available water content increased with different amendments. In this connection, Ghazy(1994) and Abd EL- Hamid et al. (2005) found that available soil moisture was increased with application of both organic material and gypsum requirements. 
Hamad .M.M.H.

5

1008 
Regarding the influence of irrigation regime, it is obvious that there was a slight decrease in available water in both surface and subsurface layer upon increasing irrigation intervals as compared with that under short one. The increasing of irrigation intervals may be affect adversely the formation and configuration of water holding pores (EL-Maghraby,1997).

Effect of soil amendments on some soil chemical properties:

Results pertaining the effect of suger industrial wastes and gypsum or sulphur added to saline sodic soil on the most parameters of chemical properties are given in Table (6). Apparently, the soil pH, EC and ESP values were greatly higher in both surface and subsurface soil layers of untreated plots, then these values were gradually decreased due to the application of different amendments, except organic matter which show opposite trend, particularly under 12 days of irrigation frequency. The efficiency of filter mud and sugar lime on reducing the values of such parameters may be rendered the formation of the organic and inorganic acids during organic materials decomposition which contribute to reduce soil $\mathrm{pH}$ values and increase O.M content.

Table (6) : Effect of soil amendments on pH, EC, ESP and O.M. in the studied soil under irrigation intervals(average two seasons)

\begin{tabular}{|c|c|c|c|c|c|c|c|c|c|}
\hline \multirow{2}{*}{$\begin{array}{l}\text { Soil } \\
\text { amendments } \\
\text { (ton/fed }{ }^{-1} \text { ) }\end{array}$} & \multirow{2}{*}{$\begin{array}{l}\text { Soil } \\
\text { depth } \\
\text { (cm) }\end{array}$} & \multicolumn{4}{|c|}{ Irrigation interval (12 days) } & \multicolumn{4}{|c|}{$\begin{array}{l}\text { Irrigation interval } \\
\text { (18 days) }\end{array}$} \\
\hline & & pH & $\begin{array}{c}E C \\
\left.(\mathrm{dSm})^{-1}\right)\end{array}$ & $\begin{array}{c}\text { ESP } \\
(\%)\end{array}$ & $\begin{array}{l}\text { O.M } \\
\text { (\%) }\end{array}$ & pH & $\begin{array}{c}E C \\
\left.(\mathrm{dSm})^{-1}\right)\end{array}$ & $\begin{array}{l}\text { ESP } \\
(\%)\end{array}$ & $\begin{array}{l}\text { O.M } \\
\text { (\%) }\end{array}$ \\
\hline \multirow{2}{*}{ Control } & $0-20$ & 8.26 & 6.21 & 17.6 & 1.26 & 8.42 & 6.21 & 17.6 & 1.26 \\
\hline & $20-40$ & 8.31 & 6.94 & 18.3 & 1.18 & 8.61 & 6.99 & 18.3 & 1.09 \\
\hline \multirow{2}{*}{ G } & $0-20$ & 8.04 & 4.72 & 15.3 & 1.32 & 8.17 & 5.00 & 15.4 & 1.27 \\
\hline & $20-40$ & 8.15 & 4.96 & 17.3 & 1.28 & 8.22 & 6.12 & 17.9 & 1.16 \\
\hline \multirow{2}{*}{ S } & $0-20$ & 7.82 & 5.02 & 16.5 & 1.36 & 7.98 & 5.31 & 15.7 & 1.32 \\
\hline & $20-40$ & 7.80 & 5.33 & 17.8 & 1.29 & 8.10 & 6.32 & 18 & 1.21 \\
\hline \multirow{2}{*}{$G+S$} & $0-20$ & 7.71 & 4.66 & 14.7 & 1.41 & 7.90 & 4.92 & 14.8 & 1.39 \\
\hline & $20-40$ & 8.04 & 4.93 & 17.6 & 1.33 & 8.10 & 5.82 & 17.4 & 1.28 \\
\hline \multirow{2}{*}{ Wastes } & $0-20$ & 8.12 & 4.86 & 13.9 & 1.46 & 8.21 & 5.24 & 14.7 & 1.41 \\
\hline & $20-40$ & 7.95 & 4.91 & 17.3 & 1.40 & 8.33 & 5.60 & 17.8 & 1.34 \\
\hline \multirow{2}{*}{ Wastes + G } & $0-20$ & 7.93 & 4.31 & 13.3 & 1.49 & 8.06 & 5.12 & 13 & 1.43 \\
\hline & $20-40$ & 7.70 & 4.80 & 17.2 & 1.42 & 8.36 & 5.51 & 17.5 & 1.37 \\
\hline \multirow{2}{*}{ Wastes + S } & $0-20$ & 7.76 & 4.72 & 12.3 & 1.53 & 7.82 & 4.61 & 12.6 & 1.49 \\
\hline & $20-40$ & 7.61 & 4.90 & 16.8 & 1.46 & 8.00 & 5.07 & 17.2 & 1.39 \\
\hline \multirow{2}{*}{ Wastes $+G+S$} & $0-20$ & 7.66 & 4.08 & 12.0 & 1.59 & 7.78 & 4.26 & 12.5 & 1.58 \\
\hline & $20-40$ & 7.52 & 4.52 & 15.9 & 1.51 & 8.00 & 4.96 & 16.6 & 1.46 \\
\hline
\end{tabular}

Also, more soluble salts were leached out by the irrigation water to the deeper soil layers. This will be reflected in decreasing EC in soil layers of 
untreated plots, then these values were gradually decreased due to the different amendments, except organic matter which show opposite trend, particularly under 12 days of irrigation frequency. The efficiency of filter mud and sugar lime on reducing the values of such parameters may be rendered the formation of the organic and inorganic acids during organic materials decomposition which contribute to reduce soil $\mathrm{pH}$ values and increase O.M content. This will be reflected in decreasing EC and ESP values, as well as transformation of sulphur to sulphoric acid by soil microorganisms along with its role in increasing the infiltration rate of the soil ( Alawi et al., 1980). Wahdan, et al. ( 1999) reported that the high reduction in $\mathrm{Na}$ ions compared to $\mathrm{Ca}+\mathrm{Mg}$ ones is reflected on decreasing the soil ESP values in the soil treated with gypsum or sulphur.

Generally, The best treatment with regard to reducing soil pH, EC and ESP values was obtained when applied 4.5 ton/ fed. sugar industrial wastes ( filter mud + sugar lime) supported by 1.0 ton/fed, gypsum and 0.5 ton/fed sulphur under 12 days irrigation interval.( Abd El-Hamid, et al., 2011 and Mansour, et al.,(2014).

\section{Effect of soil amendments on Wheat yield:}

The application of industrial wastes ( filter mud + sugar lime), sulphur and gypsum alone or combined with them led to an increase the grain, and straw yield of wheat plants as compared to the untreated soil ( control) as shown in Table (7). The combined treatments were more effective in most cases than the single application, particularly industrial wastes (filter mud + sugar lime) supported by chemical amendments ( gypsum and sulphur ) under 12 days of irrigation interval. This is possibly due to the beneficial effects of such materials on physiochemical properties affecting plant growth, i.e. soil structure, available water, soil salinity, $\mathrm{pH}$ and ESP as previously mentioned ( Tables 4, 5 and 6 ), thereby wheat plants will have a favorable environmental conditions for wheat plants to grow better with low salinity and short irrigation intervals. Besides, the decomposition of organic materials in saline sodic induced slow release of nutrients supply for growing plants ( Hashim et al., 1995).

As for the influence of irrigation intervals on plant height, and seed yield of wheat plants, data indicated that, increasing the irrigation frequency decreased the plant height, head diameter and yields of maize due to the induced relatively high total moisture stress under long irrigation intervals ( El- Kommos and Nour El-Din, 1990) beside increasing the respiration and decreasing the photosynthesis upon increasing water stress ( Ghazy et al., 1987). 
J.Soil Sci. and Agric. Eng., Mansoura Univ., Vol. 6 (8), August , 2015

7 


\section{Effect of soil amendments on water use efficiency:}

Data presented in Table ( 7 ) show, in general, that water use efficiency was more influenced by the combined treatments of soil amendments than the single ones. The maximum water use efficiency value and wheat yield $\left(1.96 \mathrm{Kg} \mathrm{m}^{3}\right)$,were obtained when filter mud + sugar lime) supported by gypsum +sulphur was added to saline sodic soil under 12 days of irrigation interval. The lowest corresponding value $\left(0.8 \mathrm{Kg} \mathrm{m}^{3}\right)$, were recorded in untrated soil ( control) under 18 days of irrigation interval for water use efficiency. This means that the combined treatments between industrial wastes (filter mud+sugear lime) and gypsum+ sulphur is adequate for maintaining favorable conditions for plant growth grown on saline sodic soil, particularly under 12 days of irrigation interval. These results agree with ElFayoumy et al., ( 1996) and El - Maghraby ( 1997 ) .

Effect of soil amendments on N.P. and K.(\%) and uptake ( $\mathrm{kg}$ fed.) in grains wheat plant.

Data in Table (8) cleared that the application of soil amendments either individually or in combination on $\mathrm{N}, \mathrm{P}$ and $\mathrm{K}$. concentrations and uptake increased, N, P and K. concentrations and uptake in the grains of wheat plant favor of the high rate.

Table (8) : Effect of soil amendments on N,P and K (\%) and uptake (kg $\mathrm{fed}^{-1}$ ) in grains wheat plant under irrigation intervals(average two seasons)

\begin{tabular}{|c|c|c|c|c|c|c|c|c|c|c|c|c|}
\hline \multirow{4}{*}{$\begin{array}{l}\text { Soil } \\
\text { amendments } \\
\text { (ton/fed) }\end{array}$} & \multicolumn{6}{|c|}{ Irrigation interval (12 days) } & \multicolumn{6}{|c|}{ Irrigation interval (18 days) } \\
\hline & \multicolumn{6}{|c|}{ Grain } & \multicolumn{6}{|c|}{ Grain } \\
\hline & $\mathrm{N}$ & $\mathrm{P}$ & K & $\mathbf{N}$ & $\mathbf{P}$ & $\mathbf{K}$ & $\mathbf{N}$ & $\mathbf{P}$ & $\mathbf{K}$ & $\mathbf{N}$ & $\mathbf{P}$ & $\mathbf{K}$ \\
\hline & \multicolumn{3}{|c|}{$(\%)$} & \multicolumn{3}{|c|}{$\mathrm{Kg} \mathrm{fed}^{-1}$} & \multicolumn{3}{|c|}{ (\%) } & \multicolumn{3}{|c|}{$\mathrm{Kg} \mathrm{fed}^{-1}$} \\
\hline Control & 1.62 & 0.62 & 0.15 & $32.6 \overleftarrow{\epsilon}$ & 6.315 & 5.01 & 1.32 & 0.42 & 0.09 & 30.6 & 6.11 & 4.71 \\
\hline $\mathrm{G}$ & 1.64 & 0.65 & 0.17 & $34.4 \epsilon$ & 6.625 & 5.23 & 1.44 & 0.45 & 0.12 & 31.4 & 6.42 & 4.83 \\
\hline $\mathrm{S}$ & 1.69 & 0.78 & 0.21 & 35.17 & 7.125 & 5.42 & 1.39 & 0.58 & 0.16 & 32.1 & 7.02 & 5.12 \\
\hline $\mathrm{G}+\mathrm{S}$ & 1.72 & 0.80 & 0.26 & 40.27 & 7.615 & 5.80 & 1.42 & 0.70 & 0.22 & 36.2 & 7.41 & 5.30 \\
\hline & 2.09 & 0,84 & 0.30 & $42.2 \mathrm{~s}$ & 9.317 & 7.90 & 1.89 & 0,74 & 0.26 & 38.2 & 9.01 & 7.50 \\
\hline Wastes + G & 2.22 & 0.96 & 0.36 & 44.6 & $11.4 \mid \varepsilon$ & 8.70 & 2.02 & 0.86 & 0.30 & 40.6 & 11.0 & 8.20 \\
\hline Wastes + S & 2.28 & 1.04 & 0.40 & 46.4 & 12.9 & 9.30 & 2.08 & 0.94 & 0.34 & 42.4 & 12.1 & 9.10 \\
\hline Wastes + G + & 2.34 & 1.11 & 0.46 & 49.3 & 16.7 & 10.6 & 2.14 & 1.00 & 0.39 & 46.3 & 16.2 & 10.1 \\
\hline
\end{tabular}

The highest values were associated with application of filter mud + sugar lime supported by gypsum + sulphur compared with untreated soil, particularly at 12 days irrigation interval in surface layer.

The best treatments were found to be $6 \mathrm{Mg}$ fed $^{-1}$. The treatments could be arranged in the following ascending order : T8 $<\mathrm{T} 7<\mathrm{T} 6<\mathrm{T} 5<\mathrm{T} 4<\mathrm{T} 3<$ $\mathrm{T} 2<\mathrm{T} 1$ under 12 days of irrigation interval, this could be attributed to the decomposition of soil amendments supplying more available nutrients as well as formation of organic and inorganic acids during decomposition which slightly reduce the soil $\mathrm{pH}$ which in turn enhanced the solubility and availability of N.,P., and K. These beneficial effects are in agreement with those ( Mansour, et al 2012 and El-Kouny,et al 2004)Similar trend was found under 18 days of irrigation interval. 


\section{CONCLUSION}

Based on the aforementioned discussion, it could be concluded that the usage of any soil amendments treatment (gypsum, sulphur, gypsum + sulphur, gypsum + sulphur combined with (filter mud + sugar lime)) could positively affect the soil physio-chemical and biological properties i.e., $\mathrm{pH}$, EC, ESP and bulk density,since it were decreased. On the contrary, the aggregates siz, particularly of $(2-1 \mathrm{~mm})$ in diameter and total water stable aggregates, and at the same time, decreased the fine aggregates size $(0.125$ $\mathrm{mm}$ ) in diameter., basic infiltration rate and available water.

wheat yield ,straw yield and water use efficiency were enhanced in response to different treatments of amendments under irrigation intervals as compared with the untreated soil. Also, these treatments increased grain content of the three nutrients elements ( $\mathrm{N}, \mathrm{P}$ and $\mathrm{K})$

\section{REFFRENCES}

Abdel- Aziz, S. M; F.S. Salem. ; M.M.A. Reda and L.A. Hussien (1998). Influence of some amendments on the clayey soil properties and crop production. Fayoum J. Agric. Res. \& Dev., 1:196-204.

Abd El-Hamid, R.; Azza, R.; T.A El- Maghraby, I.M.M. El-Banna and S.F. Mansour (2005). Effect of gypsum application and potassium fertilization on sugar beet (Beta vulgaris L.) yield and some physical properties of soil at north Nile delta. Egypt. J. of Appl. Sci., 20:656-668.

Abd El-Hamid, R.Azza, R.; S.F.Mansour; T.A.El-Maghraby and M.A.A.Bakry,(2011). Competency of some soil amendments used for improvement of extreme salinity of Sahl El-Tina soil.J.Soil Sci.and Agric. Eng.Mansoura Univ.Vol.2 (6):649- 667.

Afify, M.Y.(1983).Effect of water quality and irrigation regime on the stability of aggregation soils. Desert Inst. Bull., A.R.E.,23:197- 209-

Alawi, B.J., J.L Stroehlein, E.A. Henlon and F. Turner ( 1980). Quality of irrigation water and effects of sulphuric acid and gypsum on soil properties and sudan grass yields. Soil Sci., 129:315-327

Aly, K.M.L (1993 ). An evaluation of adding different sources of gypsum for improving soil productivity under field condition. M.Sc. Thesis, Fac. Of Agric., Ain Shams Univ., Cairo, Egypt.

El- Fayoumy, M.E., H.M. Ramadan and E.A. El-Koreish (1996). Soybean biomass, N2-fixation and water use efficiency as affected by frequency of irrigation, soil salinity and inoculation with Bradyrhizobium. Alex. J. Agric. Res., 41:313-326.

El-Kommos, F. and M. Nour El-Din (1990). The effect of irrigation frequency under varying soil amendments application on wheat and broad beans production in sandy soils. Egypt. J. Soil Sci., 30:403- 415.

El-Kouny,H.M.;A.I.Sharaf and A.M.El-Naggar (2004).Effect of compost application and lacustrine soil.J.Adv.Agric.Res.Fac.Agric.Saba Basha 9: 909-829. 
El-Maghraby, S.E. ( 1997). Impact of natural conditioners and saline irrigation water frequency of calcareous soil productivity. Egypt. J Soil Sci., 37: 267-281.

Gee, G.W. and. J. W Bauder (1986). Particle Size Analysis. In "Methods of Soil Analysis". Part 1, PP. 383-409., Klute, A.,(Ed.), Amer. Soc. Agron., Madison, WI, USA.

Ghazy, M.A. (1994). Effect of water regime, gypsum and sewage sludge increments on the improvement and productivity of saline- sodic soils. Ph.D. Thesis, Fac. of Agric., Tanat Univ., Egypt.

Ghazy, A.; A.M. Selim and M.Z. Salem ( 1987). Effect of irrigation regime on the yield of wheat and the efficiency of water use. Egypt. J. Soil Sci., 27:387-401.

Hashim, F.A.; S.E. El-Maghraby and M.M. Wassif ( 1995). Efficiency of organic manure and residual sulphur effect under saline irrigation water and calcareous soil conditions. Egypt. J. Soil sci. 35:361-374.

Hillel, D. (1980 ). Fundamentals of Soil physics. Academic press, London, New York.

Israelsen, O.W and V.E. Hansen (1962). "Irrigation Principles and Practices".3rd ed. John Wiley and Sons, Inc. NewYork.

Issac,R. and Junson, G.( 1976).Determination of total nitrogen in plant tissue using a Black Digestor.J.of Association of official Analytical chemists,59.

Jackson,M.L.( 1967). "Soil chemical Analysis" prentice Hall,Inc. Englewood, cliffs,N.J.

Jensen, M.E. (1983). Design and Operation of Farm Irrigation Systems. Am. Soc. Agron. Eng., Michigan, USA.

Kemper,W.D. and R.C.Rosenau,.(1986).Aggregate stability andsize,distribution pages 425- 442 in A.Klute,ed.Methods of soil analysis part 1.2nd ed.American Soc. Of agronomy Madison.w1.

Khafagi, M. and Y. Abdel- Hadi (1990). Effect of sulphur application on salt distribution in a sodic calcareous soil. Egypt. J. Soil Sci., 30:199-212.

Mansour, S.F.(2002). Improvement of soil structure in some soils of Egypt. Ph.D. Thesis, Fac. of Agric., Cairo Univ., Giza, Egypt.

Mansour,S.F.;M.M.Reda; Azza,R.Abd El-Hamid and F.A.Farag(2012).Effect of interaction between certain acidic amendments on amelioration of calcareous soil properties and its productivity.Egypt,J.of Appli.Sci.,27 (3).

Mansour,S.F.;M.M.Reda;M.M.H.Hamad,andE.E.E.Khafagy(2014).Utilization efficiency of different industrial by products in amelioration of saline sodic soils.J.Soil Sci.and Agric.Eng.Mansoura Univ.,Vol.5(7):997-1015.

Mohamed, R.M.; A El-Shanawany and N.M. Badr (2001). Influence of some organic manures and bio- fertilizer on soil properties and wheat yield. Fayoum J. Agric. Res. and Dev., 15:49-56.

Mohamedin. A.A.M.; M. Abdel- Warth; A.A Mahmoud and A.M. El-Melegy (2005). Effect of amendments followed by saline water on properties and productivity of highly alkali soils. Egypt. J. of Appl. Sci., 20:258-268

Page, A.L., R.H. Miller and D.R. Keeney (1982). "Methods of Soil Analysis" part 2, No.9. Am. Soc. Agron. Madison, Wis. USA. 
Reda, M.M.A.; Faten, M. Mohamed; S.F. Mansour and M.Y. Abo-Zeid (2006). Interaction between sugar lime, sulphur and applied bio- inorganic $\mathrm{N}$ fertilization on saline sodic soil properties and wheat production. Egypt. J. of Appl. Sci., 21:353-372.

Richards, L.A. (1954). Diagnosis and Improvement of Saline and Alkali Soils. USDA Handbook No.60.

Stakman,W.P. and G.G.V. Harst ( 1962). The Use of The Pressure Membrane Apparatus to Determine Soil Moisture Contents at $\mathrm{pH} 3.0$ to 40 Inclusive Inst. For land water manage.Res.note No.159.coefficients,p.1201- 1229,In D.L.Sparks(ed)Methods of Soil Analysis,part 3 .Chemical Methods,Soil Sci. Soc.of America Books,Madison,w1.

Vomocil, J.A. (1965). "Methods of Soil Analyses". Part 1 Edited by Klute, As 4

Wahdan, A.A.; S.A. El- Gendi and A.S Abdel- Mawgoud ( 1999). Amelioration techniques for sodic soils in Al- Fayoum Oasis. Egypt . J. Soil Sci., 39:199-210.

Wassif, M.M.; A.M. Elgala; M.A. Mostafa and S.E. El-Maghraby (1999). Effect of elemental sulphur and water salinity levels on ion solubility in two calcareous soils. 2nd African Soil Sci. Soc. Conf. bull. 9 . 183-188.

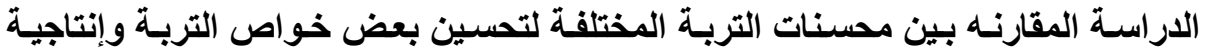
القمح في التربة الملحية الصودية المبنة

معمد محمد حسن حماد الإنة المباد

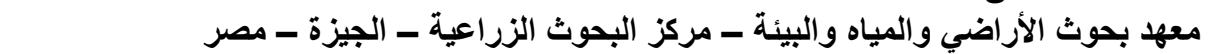

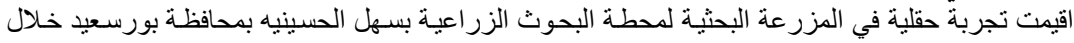

الموسم الثتوى لعام 2013/2012 و2014/2013 بغرض تعظيم الإستفادة لبعض مخلفات صناعة السكر في مصر

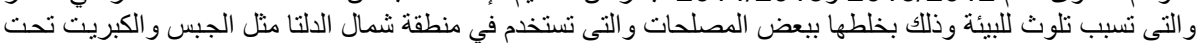
تأثير فترات الرى كأسلوب للمعالجة وإنعكاس أثره على تحسين بعض صفات التربة التربة الطبيعية والكيميائية و إنتاجيتها من

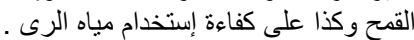

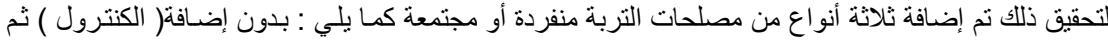

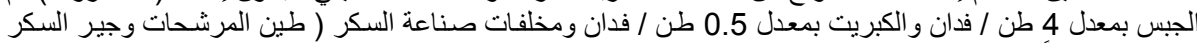

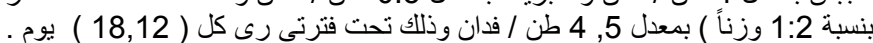

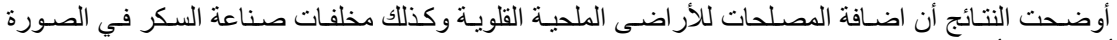

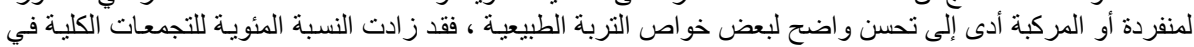

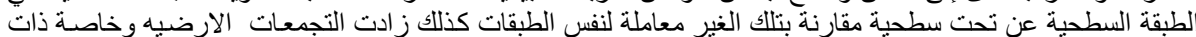

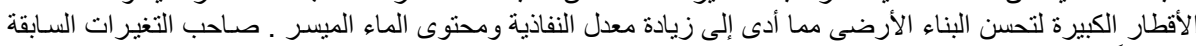

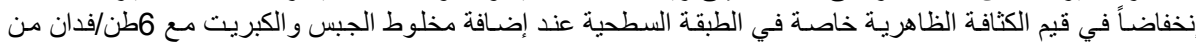

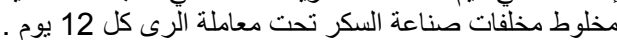

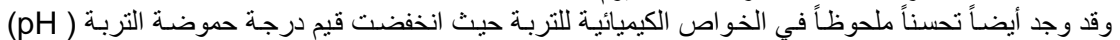

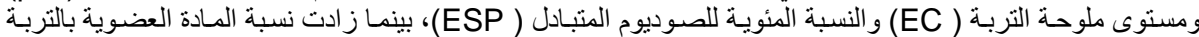

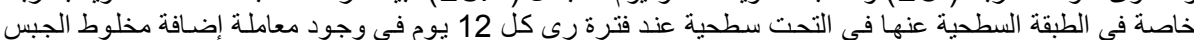

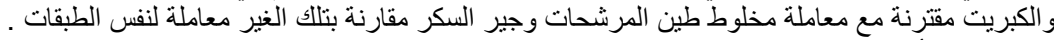

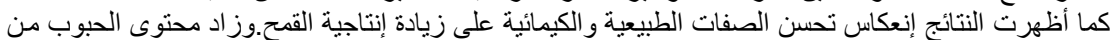

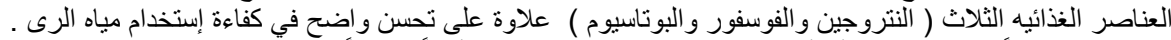

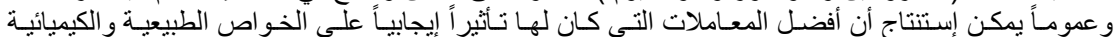

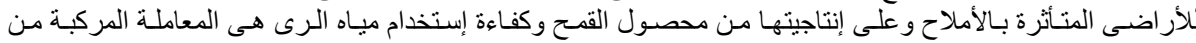

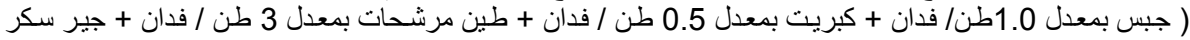
بمعدل 1.5 طن / فدان ) مع الرى كل 12 يوم . 
Table(4):Effect of soil amendments on water stable aggregates in the studied soil under irrigation intervals(average two seasons)

\begin{tabular}{|c|c|c|c|c|c|c|c|c|c|c|c|c|c|}
\hline \multicolumn{6}{|c|}{ Irrigation interval (18 days) } & \multicolumn{6}{|c|}{ Irrigation interval (12 days) } & \multirow{3}{*}{$\begin{array}{c}\text { Soil } \\
\text { depth } \\
(\mathrm{cm})\end{array}$} & \multirow{3}{*}{$\begin{array}{l}\text { Soil } \\
\text { amendments } \\
\text { (ton/fed) }\end{array}$} \\
\hline \multirow[b]{2}{*}{$\begin{array}{l}\text { TSA* } \\
(\%)\end{array}$} & \multicolumn{5}{|c|}{ Aggregate size distribution (\%) } & \multirow[b]{2}{*}{$\begin{array}{l}\text { TSA* } \\
(\%)\end{array}$} & \multicolumn{5}{|c|}{ Aggregate size distribution (\%) } & & \\
\hline & $\begin{array}{c}<0.125 \\
\mathrm{~mm}\end{array}$ & $\begin{array}{c}0.25- \\
0.125 \\
\mathrm{~mm}\end{array}$ & $0.5-0.25$ & $1-0.5$ & $\begin{array}{l}2-1 \\
\mathrm{~mm}\end{array}$ & & $\begin{array}{c}<0.125 \\
\mathrm{~mm}\end{array}$ & $\begin{array}{c}0.25- \\
0.125 \\
\mathrm{~mm}\end{array}$ & $\begin{array}{l}0.5- \\
0.25 \\
\mathrm{~mm}\end{array}$ & $\begin{array}{r}1-0.5 \\
\mathrm{~mm}\end{array}$ & $\begin{array}{l}\text { 2-1 } \\
\mathrm{mm}\end{array}$ & & \\
\hline 33.02 & 66.98 & 4.02 & 11.00 & 7.14 & 10.86 & 37.12 & 62.88 & 4.21 & 12.31 & 8.96 & 11.64 & $0-20$ & \\
\hline 28.28 & 71.72 & 3.93 & 9.36 & 6.81 & 8.18 & 32.72 & 67.28 & 4.03 & 11.33 & 8.20 & 9.16 & $20-40$ & Control \\
\hline 40.90 & 59.10 & 4.29 & 13.78 & 8.76 & 14.07 & 44.04 & 55.96 & 4.40 & 14.82 & 9.26 & 15.56 & $0-20$ & \\
\hline 35.68 & 64.32 & 4.17 & 11.37 & 8.14 & 12.00 & 38.42 & 61.58 & 4.27 & 12.42 & 8.63 & 13.10 & $20-40$ & $G$ \\
\hline 33.85 & 66.15 & 4.16 & 11.06 & 7.43 & 11.20 & 37.95 & 62.05 & 4.28 & 12.74 & 9.03 & 11.90 & $0-20$ & \\
\hline 29.71 & 70.29 & 4.00 & 9.42 & 7.16 & 9.13 & 33.66 & 66.34 & 4.07 & 11.51 & 8.27 & 9.81 & $20-40$ & $S$ \\
\hline 42.33 & 57.67 & 4.39 & 14.03 & 8.93 & 14.89 & 45.02 & 54.98 & 4.49 & 15.07 & 9.33 & 16.13 & $0-20$ & \\
\hline 37.20 & 62.80 & 4.20 & 11.76 & 8.47 & 12.77 & 39.12 & 60.79 & 4.39 & 12.69 & 8.66 & 13.47 & $20-40$ & \\
\hline 36.33 & 63.67 & 4.19 & 12.08 & 7.66 & 12.40 & 41.79 & 58.21 & 4.33 & 13.91 & 9.20 & 14.35 & $0-20$ & \\
\hline 32.61 & 67.39 & 4.10 & 10.30 & 7.49 & 10.72 & 37.36 & 62.64 & 4.16 & 12.09 & 8.49 & 12.62 & $20-40$ & Wastes \\
\hline 38.10 & 64.25 & 4.25 & 12.26 & 8.96 & 12.63 & 42.79 & 57.21 & 4.38 & 14.17 & 9.29 & 14.95 & $0-20$ & \\
\hline 34.20 & 65.80 & 4.14 & 10.50 & 8.52 & 11.04 & 38.29 & 61.71 & 4.25 & 12.33 & 8.53 & 13.18 & $20-40$ & \\
\hline 45.01 & 54.99 & 4.34 & 14.76 & 9.16 & 16.75 & 47.74 & 52.26 & 4.59 & 15.73 & 9.48 & 17.94 & $0-20$ & \\
\hline 38.15 & 61.85 & 4.21 & 12.24 & 8.60 & 13.10 & 39.83 & 60.17 & 4.40 & 12.99 & 8.73 & 13.71 & $20-40$ & stes $+S$ \\
\hline 45.61 & 54.39 & 4.51 & 14.97 & 9.31 & 16.82 & 49.10 & 50.90 & 4.85 & 16.13 & 9.52 & 18.60 & $0-20$ & \\
\hline 41.14 & 58.86 & 4.36 & 13.08 & 8.69 & 15.01 & 44.11 & 55.89 & 4.50 & 14.11 & 8.79 & 16.71 & $20-40$ & \\
\hline
\end{tabular}

- TSA= Total stable aggregates, Wastes = Sugar industrial wastes ( filter mud + sugar lime). 
Table (5): Effect of soil amendments on bulk density (B.D), basic infiltration rate (B.I.R) and available water (A.W) in the studied soil under irrigation intervals (average two seasons)

\begin{tabular}{|c|c|c|c|c|c|c|c|c|c|c|c|}
\hline \multirow{3}{*}{$\begin{array}{l}\text { Soil } \\
\text { amendments } \\
\text { (ton/fed) }\end{array}$} & \multirow{3}{*}{$\begin{array}{c}\text { Soil } \\
\text { depth } \\
(\mathrm{cm})\end{array}$} & \multicolumn{5}{|c|}{ Irrigation interval (12 day) } & \multicolumn{5}{|c|}{ Irrigation interval (18 days) } \\
\hline & & B.D. & B.I.R. & F.C & W.P & A.W & B.D. & B.I.R. & F.C & W.P & A.W \\
\hline & & $\left(\mathrm{g} / \mathrm{cm}^{3}\right)$ & $(\mathrm{cm} / \mathrm{hr})$ & $(\%)$ & (\%) & (\%) & $\left(\mathrm{g} / \mathrm{cm}^{3}\right)$ & $(\mathrm{cm} / \mathrm{hr})$ & (\%) & (\%) & (\%) \\
\hline \multirow{2}{*}{ Control } & $0-20$ & 1.22 & 1.31 & 37.53 & 18.63 & 18.90 & 1.21 & 1.29 & 34.65 & 17.3 & 17.35 \\
\hline & $20-40$ & 1.36 & 1.12 & 37.44 & 18.69 & 18.75 & 1.36 & 1.18 & 34.24 & 17.1 & 17.14 \\
\hline \multirow{2}{*}{$G$} & $0-20$ & 1.15 & 1.40 & 37.88 & 17.89 & 19.99 & 1.18 & 1.30 & 36.88 & 18.6 & 18.28 \\
\hline & $20-40$ & 1.31 & 1.19 & 37.93 & 18.21 & 19.72 & 1.33 & 1.20 & 35.13 & 17.9 & 17.23 \\
\hline \multirow{2}{*}{$S$} & $0-20$ & 1.17 & 1.37 & 38.8 & 18.28 & 19.52 & 1.19 & 1.29 & 36.8 & 19.2 & 17.60 \\
\hline & $20-40$ & 1.32 & 1.17 & 38.4 & 20.04 & 18.36 & 1.32 & 1.20 & 35.84 & 18.8 & 17.04 \\
\hline \multirow{2}{*}{$G+S$} & $0-20$ & 1.14 & 1.41 & 37.3 & 18.2 & 19.10 & 1.15 & 1.33 & 36.33 & 17.8 & 18.53 \\
\hline & $20-40$ & 1.30 & 1.20 & 37.9 & 19.08 & 18.82 & 1.29 & 1.21 & 35.11 & 17.01 & 18.10 \\
\hline \multirow{2}{*}{ Wastes } & $0-20$ & 1.19 & 1.35 & 38.7 & 19.68 & 19.02 & 1.19 & 1.32 & 37.07 & 19.3 & 17.77 \\
\hline & $20-40$ & 1.34 & 1.15 & 37.11 & 19.61 & 17.50 & 1.30 & 1.22 & 36.1 & 18.9 & 17.11 \\
\hline \multirow{2}{*}{ Wastes + G } & $0-20$ & 1.13 & 1.43 & 38.5 & 18.45 & 20.05 & 1.17 & 1.34 & 37.67 & 18.55 & 19.12 \\
\hline & $20-40$ & 1.29 & 1.21 & 38.6 & 19.38 & 19.22 & 1.27 & 1.24 & 36.94 & 17.98 & 18.96 \\
\hline \multirow{2}{*}{ Wastes + S } & $0-20$ & 1.11 & 1.43 & 38.87 & 17.98 & 20.89 & 1.16 & 1.36 & 37.35 & 18.20 & 19.15 \\
\hline & $20-40$ & 1.27 & 1.21 & 38.32 & 18.74 & 19.85 & 1.27 & 1.25 & 37.11 & 18.03 & 19.08 \\
\hline \multirow{2}{*}{ Wastes $+G+S$} & $0-20$ & 1.09 & 1.45 & 38.8 & 17.65 & 21.15 & 1.14 & 1.41 & 39.81 & 18.9 & 20.91 \\
\hline & $20-40$ & 1.25 & 1.24 & 39.2 & 18.67 & 20.53 & 1.23 & 1.26 & 38.2 & 18.25 & 19.95 \\
\hline
\end{tabular}


Hamad .M.M.H.

1018 
Table (7) :Effect of soil amendments and irrigation intervals on grain , straw yield, of wheat and water use efficiency(average two seasons)

\begin{tabular}{|c|c|c|c|c|c|c|c|c|}
\hline \multirow[b]{2}{*}{$\begin{array}{l}\text { Soil } \\
\text { amendments } \\
\text { (ton/fed) }\end{array}$} & \multicolumn{4}{|c|}{ Irrigation interval (12 days) } & \multicolumn{4}{|c|}{ Irrigation interval ( 18 days ) } \\
\hline & $\begin{array}{c}\text { Grain yield } \\
\left(\mathrm{Kg} \mathrm{fed}^{-1}\right)\end{array}$ & $\begin{array}{c}\text { Straw } \\
\text { Yield } \\
\left(\mathrm{Kg} \mathrm{fed}^{-1}\right)\end{array}$ & $\begin{array}{c}\text { Water } \\
\text { Consumptive } \\
\text { Use }\left(\mathrm{m}^{-3} \text { fed }^{-1}\right)\end{array}$ & $\begin{array}{c}\text { W.U.E } \\
\left(\mathrm{Kg} \mathrm{m}^{-3}\right)\end{array}$ & $\begin{array}{c}\text { Grain } \\
\text { yield } \\
\left(\mathrm{Kg} \mathrm{fed}^{-1}\right)\end{array}$ & $\begin{array}{c}\text { Straw } \\
\text { Yield } \\
\left(\mathrm{Kg} \mathrm{fed}^{-1}\right)\end{array}$ & $\begin{array}{c}\text { Water } \\
\text { Consumptive } \\
\text { Use }\left(\mathrm{m}^{-3} \mathrm{fed}^{-1}\right)\end{array}$ & $\begin{array}{c}\text { W.U.E } \\
\left(\mathrm{Kg} \mathrm{m}^{-3}\right)\end{array}$ \\
\hline Control & 1710 & 2020 & 2031 & 0.84 & 1434 & 1560 & 1793.4 & 0.80 \\
\hline G & 1860 & 2240 & 1764 & 1.05 & 1580 & 1780 & 1520.4 & 1.03 \\
\hline$S$ & 1980 & 2530 & 1785 & 1.11 & 1660 & 1860 & 1498.35 & 1.1 \\
\hline$G+S$ & 2160 & 2640 & 1524.35 & 1.4 & 1790 & 1980 & 1436.4 & 1.24 \\
\hline Wastes & 2230 & 2760 & 1500 & 1.48 & 1830 & 2180 & 1359.45 & 1.34 \\
\hline Wastes + G & 2410 & 2870 & 1339.8 & 1.66 & 1950 & 2213 & 1234.8 & 1.58 \\
\hline Wastes + S & 2460 & 2910 & 1313.55 & 1.87 & 2010 & 2390 & 1281 & 1.61 \\
\hline Wastes $+G+S$ & 2590 & 3050 & 1316.7 & 1.96 & 2110 & 2530 & 1144.5 & 1.84 \\
\hline
\end{tabular}

Wastes= Sugar industrial (filter mud + sugar lime), G = gypsum $\mathbf{S}=$ sulphur 